\title{
Sepharose-Avidin Column for the Binding of Biotin or Biotin-Containing Peptides
}

The method of attaching a biologically active protein e.g., an enzyme to an activated polysaccharide matrix ${ }^{1}$ has become widely used in recent years, since on the inert surface the enzyme retains most of its activity and is easy to handle. Selective purification methods for proteins based on such affinity chromatography ${ }^{2}$ were devised like the single step isolation-purification of avidin from egg white ${ }^{3}$.

We found that avidin can be coupled to Sepharose $4 B$ activated with cyanogen bromide. A column prepared of this Sepharose-avidin showed considerable biotin or dye 4 binding capacity. For binding of biotin or biotin containing peptides such columns are quite efficient, recovery of the biotin containing material may be less practical.

In a typical experiment $20 \mathrm{ml}$ agarose gel (Sepharose 4B from Pharmacia) was suspended in $20 \mathrm{ml}$ water and a solution of $2 \mathrm{~g} \mathrm{CNBr}$ in $20 \mathrm{ml}$ water was added. The $\mathrm{pH}$ was raised and maintained at about 11 by the dropwise addition of $4 \mathrm{~N} \mathrm{NaOH}$. When the $\mathrm{pH}$ did not fall any more (about $10 \mathrm{ml} 4 \mathrm{~N} \mathrm{NaOH}$ was needed) the suspension was filtered on Buchner funnel and washed with $0.1 M$ $\mathrm{NaHCO}_{3}$. To this activated gel were added $20 \mathrm{mg}$ of avidin (Worthington) in $2 \mathrm{ml} 0.1 \mathrm{M} \mathrm{NaHCO}$ and the mixture was stirred at $4^{\circ} \mathrm{C}$ for $20 \mathrm{~h}$. The Sepharose-avidin was then poured into a chromatography tube, washed with $0.1 \mathrm{M}$ $\mathrm{NaHCO}_{3}$, and finally with $0.2 M T$ phosphate buffer of $\mathrm{pH}$ 6.8. The UTV-absorption of the effluents was measured at $280 \mathrm{~nm}$ to find unbound avidin. At least $80 \%$ of the avidin was bound by the gel.

A sample of this Sepharose-avidin $(1 \mathrm{ml}$ after low speed centrifugation) turned pink when treated with a $100 \mu M$ solution of 4-hydroxyazobenzene-2'-carboxylic acid. It was washed with $3 \mathrm{ml}$ of $0.2 M$ phosphate buffer, $\mathrm{pH} 6.8$, and then titrated with a biotin solution $(0.034 \mathrm{mg} /$ mi) until the red color disappeared $(0.45 \mathrm{ml}$ biotin solution). Thus, the Sepharose-avidin has a biotin binding capacity of $0.06 \mathrm{\mu mol} / \mathrm{ml}$ or $15 \mathrm{\gamma} / \mathrm{ml}$.

The Sepharose-avidin was used to bind biotin containing fragments from a tryptic digest of methylmalonyloxaloacetic transcarboxylase ${ }^{5}$ containing tritiated biotin.
The solution, 336,000 counts $/ \mathrm{min}$ in $4.5 \mathrm{ml}$ of $0.2 \mathrm{M}$ phosphate buffer $\mathrm{pH} 6.8$ was poured over a column prepared from $4 \mathrm{ml}$ Sepharose-avidin and was washed with $0.2 M$ phosphate buffer of $\mathrm{pH} 6.8$. The column was dyed red with $5 \mathrm{ml} 100 \mu M$ 4-hydroxyazobenzene- $2^{\prime}$-carboxylate in $0.2 \mathrm{M}$ phosphate buffer of $\mathrm{pH} 6.8$, and washed with $6 \mathrm{ml}$ of the same buffer. According to previous titration this column can bind $0.24 \mu \mathrm{mol}$ of biotin. When the transcarboxylase digest was poured over the red column, its top one-third was discolored. The column was then washed with $0.2 M$ phosphate buffer and fractions of 8 $10 \mathrm{ml}$ were collected and counted. A total of 900 counts/ min was found in 4 fractions. Elution with a $6 M$ guanidine-hydrochloride-hydrochloric acid solution of $\mathrm{pH} 1.5^{3}$ removed only a total of 80,000 counts/min, or about $24 \%$ of the biotin containing fragments.

Zusammentassung. Avidin konnte an das Polysaccharid Sepharose 4B, das zuvor mit Bromcyan aktiviert wurde, gebunden werden. Um Biotin oder Biotin-haltige Peptide zu binden, erwies sich eine Sepharose-Avidin-Säule als besonders günstig.

\section{Agnes Bodanszky and M. Bodanszky}

Department of Chemistry,

Case Western Reserve University,

Cleveland (Ohio 44106, USA), 20 October 1969.

1 R. Azen, J. Porath and S. Lirnback, Niture 217, 1302 (1967).

2 P. Cuatrecasas, M. Wilcheck and C. B. Anfinsen, Biochemistry 61, $636(1968)$

3 P. Cuatrecasas and M. Wilchek, Biochem. biophys. Res. Commun. 33, 235 (1968).

4 N. M. GREen, Biochem. J. 94, 23c (1965).

5 H. G. Wood, S. H. G. Allen, R. Stjernholm and B. Jacobson, J. biol. Chem. 238, 547 (1963).

\section{Fluorometric Detection of Serotonin Using o-Phthaldialdehyde: an Improvement}

Reaction of $o$-phthaldialdehyde (OPT) with serotonin standards increases amine detcction sensitivity ${ }^{1}$ over the direct BogDanski procedure ${ }^{2}$; however, no detailed information is available concerning the blank which is a consistent problem when low concentrations of serotonin are being analyzed. The blank arises primarily from reagents and glassware and is variable and not easily controllable ${ }^{3}$. In the Bogdanski procedure, if blank fluorescence is large relative to serotonin fluorescence, the peak of maximal serotonin fluorescence $(545 \mathrm{~nm})$ may not be present but appears in the spectrum at a shorter wavelength. This apparent shift (atypicallity) is due to overlap of blank (ca. $400 \mathrm{~nm}$ wavelength) and serotonin ( $545 \mathrm{~nm}$ wavelength) emissions which are detected additively. Readings from the atypical peak or at $545 \mathrm{~nm}$ wavelength are inaccurate. We have reported ${ }^{3}$ that the blank in the serotonin-OPT method constitutes a greater problem than in the BogDANskt procedure since reagent OPT produces exaggerated primary scattering, the increased volume of $\mathrm{HCl}$ required to achieve optimal acidity ${ }^{4}$ produces greater blank fluorescence, and the peak of maximal serotonin-OPT fluorescence occurs at $473 \mathrm{~nm}$ wavelength in comparison to the maximal emission of serotonin at $545 \mathrm{~nm}$. Reported here are the advantages of a chloroform wash in the serotonin-OPT method; chloroform removes major blank emissions and reduces primary scattering.

1 R. P. Maickel and F. P. Miller, Analyt. Chem. 38, 1937 (1966). 2 D. F. Bogdanski, A. Pletscher, B. B. Brodie and S. UdenFRIEND, J. Pharmac. 117, 82 (1956).

3 J. H. Thompson, C. A. Spezta and M. Anguro, Biochem. Pharmac., submitted.

4 J. H. Thompson, C. A. Spezia and M. Angulo, Experientia 25, 927 (1969) 